\title{
Evaluation of Iron Toxicity in the Tropical Fish Leporinus friderici
}

\author{
Tainára Cunha Gemaque ${ }^{1}$, Daniel Pereira da Costa ${ }^{1}$, Leonardo Vaz Pereira ${ }^{2}$ and Kleber Campos \\ Miranda Filho*1
}

${ }^{1}$ Federal University of Minas Gerais - UFMG, Veterinary School, Av. Pres. Antônio Carlos, 6627 - Pampulha, Belo Horizonte - MG, CEP 31270-901, Brazil

${ }^{2}$ Federal Rural University of Amazônia - UFRA, Animal Science, Rod. PA 275 s/n, km 13, Zona Rural, Parauapebas - PA, CEP 68515-000,

Brazil

*Corresponding author: Kleber Campos Miranda Filho, Veterinary School, UFMG, Brazil

\section{ARTICLE INFO}

Received: 㓞 May 13, 2019

Published: May 23, 2019

Citation: Tainára Cunha Gemaque, Daniel Pereira da Costa, Leonardo Vaz Pereira, Kleber Campos Miranda Filho. Evaluation of Iron Toxicity in the Tropical Fish Leporinus friderici. Biomed J Sci \& Tech Res 18(2)-2019. BJSTR. MS.ID.003127.

Keywords: Toxic Effects; "piau”; Lethality

\begin{abstract}
The present study aimed to determine the toxicity of iron ions $\left(\mathrm{Fe}^{2+}\right.$ and $\left.\mathrm{Fe}^{3+}\right)$ in juveniles of "piau" (Leporinus friderici), by means of acute toxicity tests, observation of the opercular beat and hematology. We used 88 specimens of $L$. friderici divided into 11 treatments: control; $1 \mathrm{mg} / \mathrm{L} ; 3 \mathrm{mg} / \mathrm{L} ; 7.5 \mathrm{mg} / \mathrm{L} ; 15 \mathrm{mg} / \mathrm{L}$ and $30 \mathrm{mg} / \mathrm{L} \mathrm{of} \mathrm{Fe}{ }^{2+}$ and $\mathrm{Fe}^{3+}$ ions, obtained from buffered solutions. Biometric and physiological parameters of fish (0-96 h after intoxication), opercular beating for one minute in the first hour of exposure and blood parameters were evaluated. The results indicate a variability of the toxic effects, the two iron ions were toxic to "piau", since both in the concentration of $30 \mathrm{mg} / \mathrm{L}$, were $100 \%$ lethal to the exposed organisms. $\mathrm{Fe}^{3+}$ caused total lethality also at concentrations of $15 \mathrm{mg} / \mathrm{L}$ and $7.5 \mathrm{mg} / \mathrm{L}$. At the concentration of $1 \mathrm{mg} / \mathrm{L}$ and $3 \mathrm{mg} / \mathrm{L}$ $\mathrm{Fe}^{3+}$, the fish were tolerant and no mortality occurred. At concentrations of $1 \mathrm{mg} / \mathrm{L} ; 3$ $\mathrm{mg} / \mathrm{L} ; 7.5 \mathrm{mg} / \mathrm{L}$ and $15 \mathrm{mg} / \mathrm{L}, \mathrm{Fe}^{2+}$ also showed no mortality, decreased glutathione levels (GSH), and increased levels of hemoglobin and methaemoglobin in both groups, with higher changes in $\mathrm{Fe}^{3+}$ groups in relation to hemoglobin and methaemoglobin. Observable changes in GSH levels occurred in animals exposed to $\mathrm{Fe}^{2+}$. The two iron ions $\left(\mathrm{Fe}^{2+}\right.$ and $\left.\mathrm{Fe}^{3+}\right)$ were very toxic to the "piau" juveniles
\end{abstract}

\section{Introduction}

Toxicity is the inherent and potential capacity of the toxic agent to cause harmful effects on living organisms Borges [1]. The toxic effect is generally proportional to the concentration of the toxic agent at the site of action Klüver et al. [2].

Acute toxicity is characterized by the administration or exposure of the chemical in a single or multiple dose in a short time (hours), analyzing the adverse effects occurring within that time interval Albinati et al. [3]. The effects are due to a single contact (single dose) or multiple contacts (cumulative effects), arising immediately or over the course of a few hours or days Oga [4]. The acute toxicity test estimates the median lethal concentration (LC50) and classifies hazardous substances intoxicants and allows the establishment of permissible limits for various chemical substances, as well as assessing the impact of mixtures of pollutants on aquatic organisms of water bodies by tests simulating the natural conditions in the laboratory Qu et al. [5]. Metals from mining may be responsible for contamination of aquatic environments. Some metals, such as iron, zinc, magnesium, cobalt, are useful in small amounts as they form some cell structures. But if the limiting amount of these metals is exceeded, they will become toxic, causing problems to organisms exposed to these metals Teixeira \& Bessa [6].

The element iron is considered a heavy metal being found in high concentrations in aquatic environments near the miners that exploit this ore. In Brazil, the dam located in the municipality of Mariana - MG was built to serve as a deposit of the wastes generated during the mining process of iron, and ruptured, causing an unprecedented environmental disaster in Brazil's history Barba [7]. Iron is also regarded as an important chemical element for many living organisms (as a biometal) and is vital for survival at low concentrations as it is essential for multiple metabolic processes such as oxygen transport, DNA synthesis, electron transport, and cofactor for many proteins Bury [8]. Iron present in water can be absorbed by the fish via gills, skin or food Cottet et al. [9]. 
Excess iron dissolved in the water can cause the formation of flakes of this metal in the gills of the fish resulting in its obstruction, causing respiratory disorders (Zahedi 2014). Animals that consume diets with high levels of iron may have reduced growth, worse feed conversion, diet rejection, mortality, and histopathological damage in liver cells, where excess of iron in the body is stored Bury [8]. Fish can be used as environmental indicators, reacting immediately to any changes in the aquatic ecosystem, through physiological changes such as changes in opercular beating, unusual swimming, gill changes and feeding changes or difficulties Hundley et al. [10]. Such reactions are easily noticeable due to chemical intoxication Niencheski et al. [11]. The observable effects in the face of poisoning are various. Opercular beats are responses to changes in the aquatic environment, such as contamination by substances with toxic potential Gibson \& Mathis [12]. Blood also has elements that respond to exposure to pollutants.

The same is responsible for the transport of substances in vertebrates, this tissue being directly linked to physiological dynamics and the body's immune responses. The study of its cellular components, especially the study of glutathione (GSH), hemoglobin $(\mathrm{Hb})$ and methaemoglobin (MeHb), can provide important information about stress and innate immunity of fish Maciel et al. [13]. Some metal ions (especially copper, zinc and iron) can bind to proteins involved in neurodegeneration. It is known that iron is responsible for several neurodegenerative pathologies in humans such as Alzheimer's and Parkinson's disease Koslowski et al. [14,15]. These diseases are triggered by genetic predisposition, aging and by environmental factors such as exposure to heavy metals Tan et al. [16]. Fish are important sources of dietary iron for the human organism, contributing to the formation of hemoglobin; however, over accumulation of iron ions in the human body by ingestion of foods with excess of this element may promote neurodegeneration Wojtunik-Kulesza et al. [17]. In this way, the aquaculture activity carried out by riverine communities in water bodies affected by iron pollution can be alarming.

The "piau" Leporinus friderici (Characiformes, Anostomidae) is one of the most widely distributed species in the Neotropical region. In addition, it is considered to be one of the most abundant species in the various water systems of the Amazon region with relevant economic importance Olivatti et al. [18]. The species of the genus Leporinus present great potential for fish farming because they have good commercial acceptance Baldisserotto \& Gomes et al. [19]. Sexual maturation occurs when the individual reaches approximately $20 \mathrm{~cm}$ in total length, concentrating his reproductive period in the months of November to February. The "piau" performs seasonal reproductive migration (piracema). There is demand for $L$. friderici fingerlings for aquaculture and repopulation programs in rivers and reservoirs in much of the national territory Suplicy [20]. It is important to consider the risk of contamination of fish such as the "piau" with iron ions and the possibility of bioaccumulation and transfer to the human body through feeding. The present study aimed to determine the toxicity of iron ions $\left(\mathrm{Fe}^{2+}\right.$ and $\left.\mathrm{Fe}^{3+}\right)$ in "piau" (L. friderici) juveniles by means of acute toxicity tests, opercular beating and blood parameters.

\section{Material and Methods}

The experiments were carried out in the ichthyology laboratory of the Institute of Scientific and Technological Research of the State of Amapá - IEPA. Eighty eight specimens of "piau" (L. friderici) with an average weight of $1.70 \pm 0.68 \mathrm{~g}$ were used. All animals were measured with digital caliper QS-50 (Jakemy, China), weighed in precision digital scale $0.01 \mathrm{~g}$ BL series (Shimadzu do Brasil Comércio Limitada, Barueri, SP, Brazil). The fish were purchased at a fisherman's shop, acclimated for a week and fed daily 08:00 and 17:00 h). Water with an average temperature of $27^{\circ} \mathrm{C} \pm 1.0$ and measured using the mercury thermometer (Accumed Produtos Médico Hospitalares Ltda., Duque de Caxias, RJ, Brazil). The $\mathrm{pH}$ presented an average value of $7.25 \pm 0.75$, using a HI 98129 digital parameter (Hanna Instruments Inc, Woonsocket Rhode Island, USA). Dissolved oxygen concentrations were always close to saturation.

Feeding was suspended $24 \mathrm{~h}$ before the start of the experiment, according to the recommendations of the Brazilian Association of Technical Standards - ABNT ABNT [21] for acute fish toxicity tests. The water employed in the experimental media was treated with AquaSafe (water chlorine remover) and parasite controller Labcon Ictio (Alcon) to avoid parasites in the animals. The treatments were carried out in $2 \mathrm{~L}$ beakers (one fish per beaker) with aeration ( $24 \mathrm{~h}$ ) with the use of compressor pumps for aquariums (model U-2800, Boyu). The three "piau" specimens were divided into 11 groups and added iron in the water for the test with buffer solutions of ferrous sulphate and ferric sulphate and maintained for up to $96 \mathrm{~h}$. The concentrations tested were: control (without addition of iron); $1 \mathrm{mg} / \mathrm{L} \mathrm{Fe}^{2+}$ and $\mathrm{Fe}^{3+} ; 3 \mathrm{mg} / \mathrm{L} \mathrm{Fe}^{2+}$ and $\mathrm{Fe}^{3+} ; 7.5 \mathrm{mg} / \mathrm{L} \mathrm{Fe}^{2+}$ and $\mathrm{Fe}^{3+}$; $15 \mathrm{mg} / \mathrm{L} \mathrm{Fe}^{2+}$ and $\mathrm{Fe}^{3+} ; 30 \mathrm{mg} / \mathrm{L} \mathrm{Fe}^{2+}$ and $\mathrm{Fe}^{3+}$, the same tests were performed for each concentration, each fish being one replicate ( $\mathrm{n}$ $=8$ ). For the analysis of the effects caused by exposure to Fe, the opercular beats $(\mathrm{OB})$ were observed. At this time, the specimens were kept individually in a beaker for one minute before and after submission to the treatments cited for the period of one hour where $\mathrm{OB}$ counts were performed per minute. Mortality was also assessed throughout the experiment. For the collection of blood, the animals were collected still dying, avoiding blood clotting.

To determine the GSH, 50 microliters of whole blood were collected from caudal venous puncture with the use of heparinized capillaries, diluted 60 times in $3 \mathrm{~mL}$ cuvette, for further reading in a spectrophotometer at $412 \mathrm{~nm}$. The determination of hemoglobin was performed according to the methodology described by Clark et al. [22]. Blood samples were collected from the dying fish and analyzed immediately in a spectrophotometer at $540 \mathrm{~nm}$. Methemoglobin levels (MeHb) were determined according to Benesch et al. [23], also with the use of capillaries with heparin, with subse- 
quent reading made at $630 \mathrm{~nm}$ in a spectrophotometer. The data were submitted to non-parametric ANOVA by the Kruskal-Wallis test by the INFOSTAT version 2017 program Casanoves et al. [24]. Significant differences were considered when the value of $\mathrm{p}<0.05$.

\section{Results and Discussion}

The results of the iron ion toxicity in juveniles of $L$. friderici indicated variability of the toxic effects. $\mathrm{Fe}^{3+}$ showed toxicity at lower concentrations and at shorter exposure times in comparison with $\mathrm{Fe}^{2+}$. Total lethality was observed after $3 \mathrm{~h}$ of exposure at concentrations of $7.5 \mathrm{mg} / \mathrm{L} ; 15 \mathrm{mg} / \mathrm{L}$ and $30 \mathrm{mg} / \mathrm{L} \mathrm{Fe}^{3+}$. $\mathrm{Fe}^{2+}$ ions showed lower toxicity, but the total lethality was observed in 24 $\mathrm{h}$ of exposure at $30 \mathrm{mg} / \mathrm{L} \mathrm{Fe}^{2+}$ concentration. At concentrations of $1 \mathrm{mg} / \mathrm{L} ; 3 \mathrm{mg} / \mathrm{L} ; 7.5 \mathrm{mg} / \mathrm{L}$ and $15 \mathrm{mg} / \mathrm{L} \mathrm{Fe}^{2+}$, no mortalities were observed after $96 \mathrm{~h}$ of exposure (Table 1). It was observed that for $30 \mathrm{mg} / \mathrm{L} \mathrm{Fe}^{2+}(1 \mathrm{~h}=112.25 \pm 1.96 \mathrm{OB} / \mathrm{min}, 24 \mathrm{~h}=$ total lethality $) ; 15$ $\mathrm{mg} / \mathrm{L} \mathrm{Fe}^{2+}(1 \mathrm{~h}=97.88 \pm 2.17 \mathrm{OB} / \mathrm{min}) ; 7.5 \mathrm{mg} / \mathrm{L}$ de íons $\mathrm{Fe}^{2+}(1 \mathrm{~h}=$ $87.38 \pm 3,62 \mathrm{OB} / \mathrm{min} ; 96 \mathrm{~h}=$ no lethality $), 3 \mathrm{mg} / \mathrm{L} \mathrm{Fe}^{2+}(1 \mathrm{~h}=83.63 \pm$ $13.3 \mathrm{OB} / \mathrm{min} ; 96 \mathrm{~h}=$ no lethality $) ; 1 \mathrm{mg} / \mathrm{L} \mathrm{Fe}^{2+}(1 \mathrm{~h}=78.5 \pm 1.60 \mathrm{OB} /$ $\min ; 96 \mathrm{~h}=$ no lethality).

Table 1: Mortality in "piau" juveniles after acute exposure to iron ions $\left(\mathrm{Fe}^{2+}\right.$ and $\left.\mathrm{Fe}^{3+}\right)$ in water for 96 hours.

\begin{tabular}{|c|c|c|}
\hline $\begin{array}{l}\text { Total nominal concentration of iron ions } \\
\qquad(\mathrm{mg} / \mathrm{L})\end{array}$ & $\mathbf{n}$ & Mortality (\%) \\
\hline \multicolumn{3}{|l|}{$\mathrm{Fe}^{2+}$} \\
\hline 0 (control) & 8 & $0 \pm 0.0$ \\
\hline 1 & 8 & $0 \pm 0.0$ \\
\hline 3 & 8 & $0 \pm 0.0$ \\
\hline 7.5 & 8 & $0 \pm 0.0$ \\
\hline 15 & 8 & $0 \pm 0.0$ \\
\hline 30 & 0 & $100 \pm 0.0$ \\
\hline \multicolumn{3}{|l|}{$\mathbf{F e}^{3+}$} \\
\hline 0 (control) & 8 & $0 \pm 0.0$ \\
\hline 1 & 8 & $0 \pm 0.0$ \\
\hline 3 & 8 & $0 \pm 0.0$ \\
\hline 7.5 & 0 & $100 \pm 0.0$ \\
\hline 15 & 0 & $100 \pm 0.0$ \\
\hline 30 & 0 & $100 \pm 0.0$ \\
\hline
\end{tabular}

Tests that presented the highest lethality were those performed with $\mathrm{Fe}^{3+}$. It was observed that at $30 \mathrm{mg} / \mathrm{L} \mathrm{Fe}^{3+}(1 \mathrm{~h}=128.25 \pm 3.41$ $\mathrm{OB} / \mathrm{min} ; 3 \mathrm{~h}=$ total lethality); $15 \mathrm{mg} / \mathrm{L} \mathrm{Fe}^{3+}(1 \mathrm{~h}=98.50 \pm 3.63 \mathrm{OB} /$ $\min ; 3 \mathrm{~h}=$ total mortality); $7.5 \mathrm{mg} / \mathrm{L} \mathrm{Fe}^{3+}(1 \mathrm{~h}=94.38 \pm 5.73 \mathrm{OB} /$ $\min ; 3 \mathrm{~h}=$ total lethality); $3 \mathrm{mg} / \mathrm{L} \mathrm{Fe}^{3+}(1 \mathrm{~h}=84.50 \pm 2.88 \mathrm{BO} / \mathrm{min}$; $96 \mathrm{~h}=$ no lethality $) ; 1 \mathrm{mg} / \mathrm{L} \mathrm{Fe}^{3+}(1 \mathrm{~h}=79.88 \pm 2.03 \mathrm{OB} / \mathrm{min} ; 96 \mathrm{~h}$ = no lethality). Iron is an element considered to be of low toxicity at concentrations below $3 \mathrm{mg} / \mathrm{L}$ and can cause harmful effects to fish in their soluble form $\left(\mathrm{Fe}^{2+}\right.$ or $\left.\mathrm{Fe}^{3+}\right)$, as demonstrated by Geertz Hansen \& Rasmussen [25]. According to these authors, iron soluble at concentrations higher than $0.5 \mathrm{mg} / \mathrm{L}$ caused a significant decrease in survival in trout larvae (Salmo trutta).
In the present study, lethality was lower when fish was exposed to $\mathrm{Fe}^{2+}, 30 \mathrm{mg} / \mathrm{L}$ ( $24 \mathrm{~h}=$ total lethality); $15 \mathrm{mg} / \mathrm{L}$ ( $24 \mathrm{~h}=$ no lethality); $7.5 \mathrm{mg} / \mathrm{L}$ ( $96 \mathrm{~h}=$ no lethality); $3 \mathrm{mg} / \mathrm{L}$ ( $96 \mathrm{~h}=$ no lethality). Studies show that other species of fish are tolerant to these concentrations of iron ions, such as zebra fish Danio rerio. According to Chua et al. [26] D. rerio has accumulated iron in the liver when exposed to $50 \mathrm{mg} / \mathrm{L}$, suggesting that this metal could be accumulated in this organ. Significant increases were observed when compared to the control group ( $92.00 \pm 05.95 \mathrm{BO} / \mathrm{min})$, to the groups intoxicated with $30 \mathrm{mg} / \mathrm{L}$ of $\mathrm{Fe}^{3+}$ and $\mathrm{Fe}^{2+}(\mathrm{p}<0.05)$ in the first hour (while all the specimens were still alive)(Table 2).

Table 2: Opercular beating in "piau" juveniles after acute exposure to iron ions $\left(\mathrm{Fe}^{2+}\right.$ and $\left.\mathrm{Fe}^{3+}\right)$ in the water during the first hour of testing.

\begin{tabular}{|c|c|}
\hline $\begin{array}{c}\text { Total nominal concentration of iron } \\
\text { ions (mg/L) }\end{array}$ & Opercular beats / minute \\
\hline \multicolumn{2}{|c|}{$\mathrm{Fe}^{2+}$} \\
\hline 0 (control) & $92.00 \pm 05.95^{\mathrm{bc}}$ \\
\hline 1 & $78.50 \pm 1.60^{\mathrm{a}}$ \\
\hline 3 & $83.63 \pm 13.30^{\mathrm{ab}}$ \\
\hline 7.5 & $87.38 \pm 3.62^{\mathrm{ab}}$ \\
\hline 15 & $97.88 \pm 2.17^{\mathrm{cd}}$ \\
\hline 30 & $112.25 \pm 1.96^{\mathrm{d}}$ \\
\hline & \\
\hline $0($ control) & $92.00 \pm 5.95^{\mathrm{bc}}$ \\
\hline 1 & $79.88 \pm 2.03^{\mathrm{a}}$ \\
\hline 3 & $84.50 \pm 2.88^{\mathrm{ab}}$ \\
\hline 7.5 & $94.38 \pm 5.73^{\mathrm{bc}}$ \\
\hline 15 & $98.50 \pm 3.63^{\mathrm{cd}}$ \\
\hline 30 & $128.25 \pm 3.41^{\mathrm{d}}$ \\
\hline
\end{tabular}

Different letters in the same column showed significant differences $p<0.05$ by the Kruskal-Wallis test.

The increase in opercular beats was higher in the groups contaminated with $\mathrm{Fe}^{3+}$ ions, since this was the most toxic ion. With the increase of the concentrations to $7.5 \mathrm{mg} / \mathrm{L}, 15 \mathrm{mg} / \mathrm{L}$ and $30 \mathrm{mg} / \mathrm{L} \mathrm{Fe}^{3+}$, the beats changed, because, with the increase of this ion in water, dissolved oxygen (DO) decreased, causing the animals to keep their swimming altered in search of oxygen, provoking a growing stress in the organism since the search for oxygen increases along with BO. The liver, gills and skin are the major sites of iron deposition and storage under conditions of overload, the liver metabolizes excess iron in the plasma and stores it in the form of ferritin and hemosiderin Chua et al. [26]. The variation in the number of opercular beats is related to the concentrations of $\mathrm{Fe}^{2+}$ and $\mathrm{Fe}^{3+}$ from which L. friderici was submitted.

At low concentrations $3 \mathrm{mg} / \mathrm{L}$ and $1 \mathrm{mg} / \mathrm{L}$ of the two ions, there was little oscillation in the beats, because they are concentrations in which the organism can survive and make sufficient withdrawal of DO from the water to supply its needs Watanabe et al. [27]. Bury 
et al. [28] concluded that the ferrous form $\left(\mathrm{Fe}^{3+}\right)$ is more toxic than the ferric form $\left(\mathrm{Fe}^{2+}\right)$ for European plaice (Platichtys flesus) and iron uptake occurred mostly in the final part of the intestine. The most important factors that may influence iron uptake are the proportions of the mineral in organic and inorganic form (in feed and water), the amount ingested and the physiological conditions of the digestive tract Watanabe et al. [27]. In fish, the initial site of accumulation of metals absorbed from water is the gill tissue Zahedi et al. According to NRC [29], one of the effects of Fe toxicity on fish is loss of growth.

Glutathione levels decreased in the contaminated groups when compared to the control group (Figure 1). The greatest decrease in GSH occurred in the group contaminated with $\mathrm{Fe}^{2+}$, the time of exposure in these groups was higher, because it was where the greatest survival occurred during the $96 \mathrm{~h}$ of experiment, occurring only in the group of $30 \mathrm{mg} / \mathrm{L} \mathrm{Fe}^{2+}$ in $24 \mathrm{~h}$. In the groups contaminated with $\mathrm{Fe}^{3+}$, there was a lower decrease in GSH levels, since the exposure time was lower, that is, in less than $24 \mathrm{~h}$ there were total lethality in the groups of 30 to $3 \mathrm{mg} / \mathrm{L}$ of $\mathrm{Fe}^{3+}$.

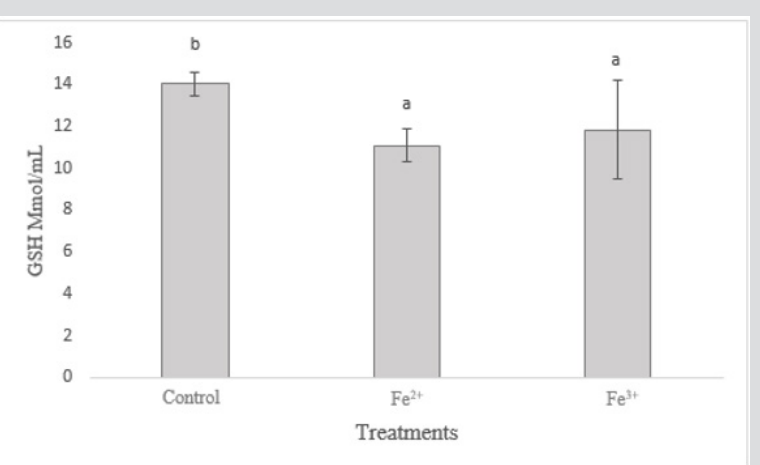

Figure 1: Levels of glutathione (GSH) in L. friderici exposed to iron ions $\left(\mathrm{Fe}^{2+}\right.$ and $\left.\mathrm{Fe}^{3+}\right)$.

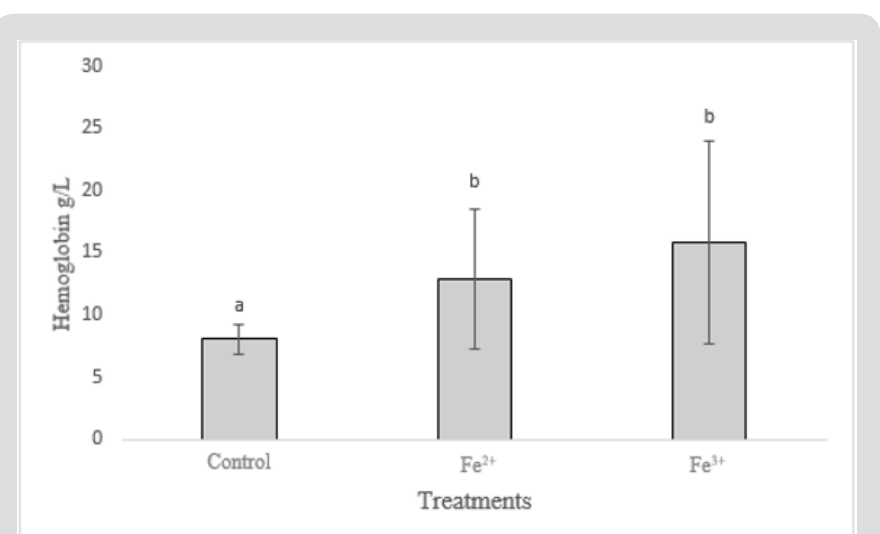

Figure 2: Levels of hemoglobin in L. friderici exposed to iron ions $\left(\mathrm{Fe}^{2+}\right.$ and $\left.\mathrm{Fe}^{3+}\right)$.

GSH can be considered one of the most important agents in the defense of cells against oxidative stress and plays a central role in the biotransformation and elimination of pollutants. This molecule has a reducing role in many reactions of peroxides and free radicals Huber et al. [30]. According to Van Der Oost et al. [31], the decrease in GSH concentration would indicate acute stress, affecting the immune system, the nervous system, and the gastrointestinal system. There was an increase in hemoglobin levels in the contaminated groups in relation to the control group (Figure 2). It is noted that increased hemoglobin may be associated with increased energy/oxygen demand by the body, which usually occurs in acute stress situations.

In the groups contaminated with $\mathrm{Fe}^{3+}$, the hemoglobin increase was more relevant, due to the toxicity of this contaminant being greater and causing damage to the organism in a shorter time. With the $\mathrm{Fe}^{2+}$ contaminated groups, there was also an increase, but smaller when compared to the $\mathrm{Fe}^{3+}$ treatments. Fish exposed to $\mathrm{Fe}$ ions have demonstrated a functional increase in blood hemoglobin levels, as $\mathrm{Hb}$ is converted to $\mathrm{MeHb}$, causing intoxication in animals Aggergaard et al. [32]. Iron is involved in hepatic processes, and is also associated with oxygen transport through $\mathrm{Hb}$, being considered one of the most important elements for fish homeostasis (Neves 2016). However, excess iron dissolved in the water can cause iron flakes to form in the gills of the fish resulting in their obstruction, causing respiratory disorders BURY et al. [8] and the increase of OB to overcome this provoked deficiency. In acute cases of iron poisoning there may be necrosis of the gill tissue and loss of ammonia excretion capacity that is concentrated in the blood of the fish Slaninova et al. [33].

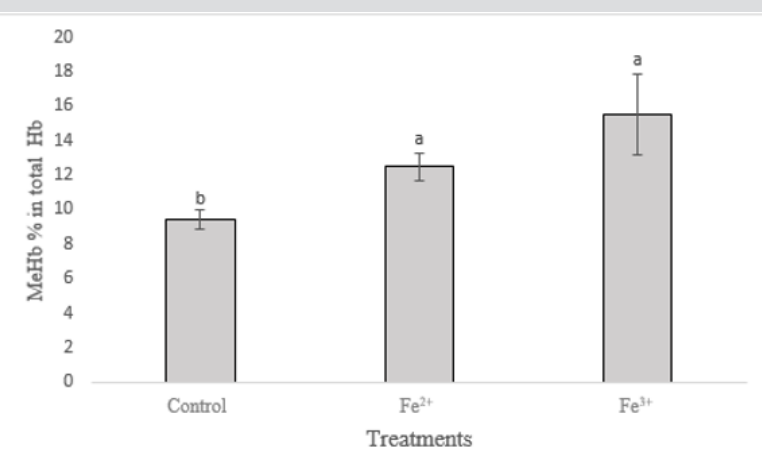

Figure 3: Methemoglobin levels in L. friderici exposed to iron ions $\left(\mathrm{Fe}^{2+}\right.$ and $\left.\mathrm{Fe}^{3+}\right)$.

Methemoglobin levels increased in groups contaminated with iron ions (Figure 3). The increase of $\mathrm{MeHb}$ in the organisms exposed to $\mathrm{Fe}^{3+}$ was higher in relation to the control group and the fish exposed to $\mathrm{Fe}^{2+}$, the latter being also larger than the control. It has already been shown that $\mathrm{Fe}^{3+}$ are more lethal than $\mathrm{Fe}^{2+}$, thus toxicological effects are more conspicuous in the groups contaminated with this pollutant. The most important effect of iron on fish refers to the ability of this compound to oxidize $\mathrm{Hb}$ in the blood, converting it to $\mathrm{MeHb}$ Jensen [34], making it impossible to transport oxygen to tissues and possibly causing the death of the animal through asphyxia Avilez et al. [35]. In humans, the malfunctioning in the iron metabolism or its excess in the organism, generated oxidative stress and the production of oxygen radicals, being able to be 
related to Parkinson's and Alzheimer's disease Kozlowski et al. [15]. However, it is not known whether this accumulation is the cause or consequence of this disease Bury et al. [8]. Inflammatory problems of the central nervous system have been reported due to excess iron causing neuronal degradation Andersen et al. [36]. Therefore, it is advisable to avoid the consumption of fish contaminated with iron ions $[37,38]$.

\section{Conclusion}

The two iron ions $\left(\mathrm{Fe}^{2+}\right.$ and $\left.\mathrm{Fe}^{3+}\right)$ are toxic to the "piau", and $\mathrm{Fe}^{2+}$ was toxic only at the concentration of $30 \mathrm{mg} / \mathrm{L}$. Fe ${ }^{3+}$ causes total lethality at concentrations of $30 \mathrm{mg} / \mathrm{L}, 15 \mathrm{mg} / \mathrm{L}, 7.5 \mathrm{mg} / \mathrm{L}$. At concentrations below $3 \mathrm{mg} / \mathrm{L} \mathrm{Fe}^{3+}$, the organism tolerates acute exposure with no mortality. Therefore, $\mathrm{Fe}^{2+}$ is less toxic when compared to $\mathrm{Fe}^{3+}$, being tolerated by L. friderici at concentrations below $30 \mathrm{mg} / \mathrm{L}$ for $96 \mathrm{~h}$ of exposure. When compared to the control group, the opercular beats (OB) were higher with the concentrations of $30 \mathrm{mg} / \mathrm{L}$ with both iron ions. Considering the above, it is possible to observe that the decrease of GSH occurs in both groups, being higher in the group contaminated with $\mathrm{Fe}^{2+}$ ions, in these groups the survival time was higher, thus increasing the exposure to the pollutant. It is observed that the increase of hemoglobin was higher in the groups contaminated with $\mathrm{Fe}^{3+}$, since this one is more toxic. In the groups contaminated with $\mathrm{Fe}^{2+}$ also increased, but smaller when compared to the $\mathrm{Fe}^{3+}$ groups. Methaemoglobin increased in the $\mathrm{Fe}^{3+}$ groups, being higher in relation to the control group and the $\mathrm{Fe}^{2+}$ groups, and the latter being also larger than the control group.

\section{References}

1. Borges R, Keita H, Ortiz B, Sampaio TIS, Ferreira IM, et al. (2018) Antiinflammatory activity of nanoemulsions of essential oil from Rosmarinus officinalis $L$ : in vitro and in zebrafish studies. Inflammopharm 26(4): 1057-1080.

2. Klüver N, König M, Ortmann J, Massei R, Paschke A, et al. (2015) Embryo Toxicity Test: Identification of Compounds with Weak Toxicity and Analysis of Behavioral Effects to Improve Prediction of Acute Toxicity for Neurotoxic Compounds. Environmental Science and Technology 49(11): 7002-7011.

3. Albinati ACL, Soares PC, Albinati RCB, Moreira ELT, Lima AD, et al. (2017) Toxicity of thiamethoxam insecticide for pacamã (Lophisiolurus alexandri). Pesquisa Pesquisa Brasileira 37(4): 307-312.

4. Oga S (2014) Fundamentos de toxicologia. Atheneu, Rio de Janeiro, RJ.

5. Qu R, Wang X, Liu Z, Yan Z, Wang Z (2013) Development of a model to predict the effect of water chemistry on the acute toxicity of cadmium to Photobacterium phosphoreum. Journal of Hazardous Materials 262: 288-296.

6. Teixeira MGC, BESSA ES (2009) Estratégias para compatibilizar desenvolvimento econômico.

7. Barba MD (2015) Mesmo sem ser tóxica, lama de barragem em Mariana deve prejudicar ecossistema por anos. In BBC Brasil.

8. Bury N, Grosell M (2003) Iron acquisition by teleost fish. Comparative Biochemistry and Physiology 135(2): 97-105.

9. Cottet M, Descloux S, Guédant P, Godon A, Cerdan P, et al. (2015) Total iron concentrations in waters and fish tissues in the Nam Theun 2 Reservoir area (Lao PDR). Environtal Monitoring and Assessentment
187(8): 529.

10. Hundley G, Navarro R (2018) Integration of Nile tilapia (Oreochromis niloticus L) production Origanum majorana L and Ocimum basilicum L using aquaponics technology. Acta Scientiarum. Technology 40: e35460.

11. Niencheski LF, Milani MR, Milani I (2008) Metais traço: Água. In: Baptista NJA, Walner Kersanach M, Patchineelam SM Poluição Marinha. Rio de Janeiro: Interciência pp. 412.

12. Gibson A, Mathis A (2006) Opercular beat rate for rainbow darters Etheostoma caeruleum exposed to chemical stimuli from conspecific and heterospecific fishes. Journal of Fish Biology 69(1): 224-232.

13. Maciel PO, Silva LCCP, Rodrigues APC, Lima FS, Barros RCR, et al. (2016) Características hematológicas, de espécimes mantidos em laboratório, da espécie de peixe amazônica Astronotus ocellatus (Agassiz, 1831) (Perciformes, Cichlidae), introduzida em outras bacias hidrográficas brasileiras. Revista Novo Enfoque- Cadernos de Saúde e Meio Ambiente 21: $1-7$

14. Koslowski H, Janka Klos A, Brajun J, Gaggelli G, Valensin D, et al. (2009) Copper, iron and zinc ions homeostasis and their role in neuro degenerative and disorders (metal uptake, transport, distribution and regulation). Coordination Chemistry Reviews 253(21-22): 2665-2685.

15. Koslowski H, Luczkowski M, Remelli M, Valensin D (2012) Copper, zinc and iron neuroregenerative diseases (Alzheimer's, Parkinson's and Prion diseases). Coordination Chemistry Reviews 256(19-20): 21292141.

16. Tan SH, Kami V, Tay NWR, Chang KH, Ah HY, et al. (2019) Emerging patways to neurodegradation: Dissecting the critical molecular mechanismis in Alzheimer's disease, Parkinson's disease. Biomedicine and Pharmacotherapy 111: 765-777.

17. Wojtunik Kulesza K, Oniszcuk A, Waksmandzka Hajnos M (2019) An Attempt to elucidate the role of iron and zinc ions in development of Alzheimer's and Parkinson's diseases. Biomedicine and Paharmacotherapy 111: 1277-1289.

18. Olivatti AM, Boni TA, Silva Júnior NJ, Resende L (2011) Short communication heterologous amplification and characterization of microsatellite markers in the Neotropical fish Leporinus friderici. Genetics and Molecular Research 10(3): 1403-1408.

19. Baldisserotto B, Gomes CL (2013) Espécies nativas para piscicultura no Brasil. In: Tataje, RD; Filho ZE (Eds.), Cultivo do gênero Leporinus. (3 edn.). UFMS.

20. Suplicy FM (2007) Freshwater fish seed resources in Brazil. In: Bondad RMG (Eds.), Assessment of freshwater fish seed resources for sustainable aquaculture. FAO Fisheries Technical Paper 501: 129-143.

21. Associação Brasileira da Normas Técnicas (1993) NBR 12714: água ensaios de toxicidade aguda com peixes. Parte I- sistema estático. Rio de Janeiro p. 15.

22. Clark TD, Sandblom E, Cox GK, Hinch SG, Farrell AP (2008) Circulatory limits to oxygen supply during an acute temperature increase in the Chinook salmon (Oncorhynchus tshawytscha). American Journal of Physiology A 295(5): 1631-1639.

23. Benesch RE, Benesch R, Yung S (1973) Equations for the spectrophotometric analysis of hemoglobin mixtures. Analytical Biochemistry 55(1): 215-218.

24. Casanoves F, Balzarini MG, Di Rienzo JA, Gonzalez L, Tablada M, et al. (2012) InfoStat. User Manual, Córdoba, Argentina.

25. Geertz Hansen P, Rasmussen G (1994) Influence of ochre and acidification on the survival and hatching of bronw trout eggs (Salmo trutta). In Muller R Lloyd R (ed) Sublethal and chronic effects os pollutants on freshwater fish, cap 18 pp. 196-210.

26. Chua ACG, Graham RM, Trinder D, Olynyk JK (2007) The regulation of cellular iron metabolism. Critical Reviews in Clinical Laboratory Sciences 44(5-6): 413-459. 
27. Watanabe T, Kiron V, Satoh S (1997) Trace minerals in fish nutrition. Aquaculture 151(1-4): 185-207.

28. Bury NR, Grossel M, Wood CM, Hogstrand C, Wilson RW, et al. (2001) Intestinal iron uptake in the European flounder (Platychtys flesus) Journal of Experimental Biology 204: 3779-3787.

29. National Research Council (2011) Nutrient Requirements of Fish and Shrimp, National Academy Press, USA DC.

30. Huber PC, Almeida WP, Fatima AD (2008) Glutationa e enzimas relacionadas: papel biológico e importância em processos patológicos. Química Nova 31(5): 1170-1179.

31. Van Der Oost R, Beyer J, Vermeulen NPE (2003) Fish bioaccumulation and biomarkers risk assessment: a review. Environmental Toxicology and Pharmacology 13(2): 57-149.

32. Aggergaard S, Jensen FB (2001) Cardiovascular changes and physiological response during nitrite exposure in rainbow trout. Journal of Fish Biology 59(1): 13-27.

33. Slaninova A, Machova J, Svobodova Z (2014) Fish kill caused by aluminium and iron contamination in a natural pond used for fish rearing: a case report. Veterinary Medicine 59(11): 573-581.

\section{ISSN: 2574-1241}

DOI: 10.26717/BJSTR.2019.18.003127

Kleber Campos Miranda Filho. Biomed J Sci \& Tech Res

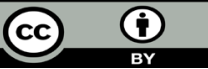

This work is licensed under Creative Commons Attribution 4.0 License

Submission Link: https://biomedres.us/submit-manuscript.php
34. Jensen FB (2003) Nitrite disripts multiple physiological functions in aquatic animals. Comparative Biochemistry and Physiology Part A 135(1): 9-24

35. Avilez IM, Aguiarl H, Hori TS, Moraes G (2013) Metabolic responses of matrinxã, Brycon amazonicus (Spix \& Agassiz, 1829) exposed to environmental nitrite. Aquaculture Research 44(4): 596-603.

36. Andersen HH, Johnsen KB, Moos T (2014) Iron deposits in the chronically inflamed central nervous system and contributes to neurodegeneration. Cellular and Molecular Life Sciences 71(9): 1607-1622.

37. Chen PJ, Tan SW, Wu WL (2012) Stabilization or Oxidation of Nanoscale Zerovalent Iron at Environmentally Relevant Exposure Changes Bioavailability and Toxicity in Medaka Fish. Environmental Science and Technology 46(15): 8431-8439.

38. Silva LMA (2014) Composição, estrutura e distribuição da ictiofauna do rio Matapi, Estado do Amapá. Tese (Doutorado). Programa de Pós Graduação em Biodiversidade Tropical, UNIFAP.

$\begin{array}{ll}\text { BIOMEDICAL } & \text { Assets of Publishing with us } \\ \text { RESEARCHES } & \text { - Global archiving of articles } \\ & \text { - Immediate, unrestricted online access } \\ & \text { - Rigorous Peer Review Process } \\ \end{array}$

